\title{
Prevention and treatment of thrombocytopenia in dengue patients: A narrative review
}

\author{
Nabeel Siddique ${ }^{1}$ (D) \\ ${ }^{1}$ Hamdard University, Hamdard Institute of Pharmaceutical Science, Islamabad Pakistan
}

ORCID IDs of the authors: N.S. 0000-0002-7339-3568

Cite this article as: Siddique, N. (2021). Prevention and treatment of thrombocytopenia in dengue patients: A narrative review. istanbul Journal of Pharmacy, 51(3), 411-418.

\begin{abstract}
Background and Aims: Dengue fever is a major health concern, especially in developed countries, because it often leads to undifferentiated febrile illness such as dengue haemorrhagic fever and dengue shock syndrome or expanded dengue syndrome, which are often reported with thrombocytopenia (TCP) and turn out to be hazardous to life. The WHO reported 23 million dengue cases and 82,000 deaths between 1955-2012. 2019 was a hallmark for the dengue epidemic from Latin America to South Asia. Due to unavailability of a dengue vaccine and antiviral therapies, additional medical attention and effort are required to treat thrombocytopenia (TCP). These approaches include thrombopoietin receptor agonists such as Oprelvekin, Eltrombopag, Romiplostim and corticosteroids, and platelet transfusion and intravenous immunoglobulin transfusions. The outcomes might not be achievable unless the proper assessment is carried out to evaluate these approaches to treat TCP in dengue patients. This narrative review aims to summarize the findings regarding the treatment of TCP in patients affected by the dengue virus.

Methods: A total of 55 published articles, including clinical trials, descriptive studies and case studies were reviewed regarding treatment of TCP in the context of dengue infection. The electronic databases PubMed, Cochrane Library, Google Scholar and Science Direct were searched for articles published from January 1990 to June 2020.

Conclusions: We concluded that dengue fever is becoming a global health concern. Premedical attention like the use of corticosteroids, Thrombopoietin receptor agonist (TPO-R) agonists and transfusions like (PT \& IVIG) are not fully assessed by double-blind randomized clinical trials and cost-effectiveness analysis. However, as compared to other treatment approaches, the use of TPO-R agonists seems to be more suitable in TCP management due to its easy access and compliance.
\end{abstract}

Keywords: Thrombocytopenia in dengue, Dengue fever, TPO-R agonist

\section{INTRODUCTION}

Dengue is a major human insect-borne viral disease and its pathogen Dengue Virus (DV) is a single strand ribonucleic virus belonging to the family Flaviviridae (Monath, 2007). Approximately 23 million dengue cases and 82,000 deaths were reported by the World Health Organization (WHO) from 1955 to 2012 (Ruberto, Marques, Burke, \& Van Panhuis, 2015). The year 2019 was marked with increased epidemics of dengue cases from Latin America to Southeast Asia. According to the Pan American Health Organization (PAHO), 236,372 cases were reported and 80,000 tests confirmed cases, while 68 deaths were solely found in America. It is estimated that cases of dengue in 2019 increased by up to 40\% compared to the cases in 2018 (Hosangadi, 2019). In December 2019, WHO Pakistan and the Ministry of National Health Services, Regulations and Coordination (MNHSR\&C) announced that there were 998 new cases in Pakistan. In the same epidemiological week (week 51), 100 cases were confirmed in Sudan. 
Clinical presentations of dengue infection vary from symptomless to serious diseases and can be one of the causes of death if left untreated. The symptomatic cases of dengue infection often show undifferentiated febrile illness; i) Dengue Fever (DF), ii) Dengue Haemorrhagic Fever (DHF), iii) Dengue Shock Syndrome (DSS) or Expanded Dengue Syndrome (EDS) (Kalayanarooj, 2011). DF stated as a non-specific febrile state, which is generally denoted as the transmission of the virus from an infected person through mosquito bite to another person, results in a mild to severe fever, general body pain, weakness, arthralgia, myalgia and rashes on the skin. On the other hand, DHF is observed among 1\% - 5\% of cases and leads to some critically serious issues such as plasma leakage, haemorrhage, ascites and reduction in leukocytes and platelets (Roy, 2019). Thrombocytopenia (TCP) is a medical condition in which blood has a lower than normal number of blood cell fragments called platelets or thrombocytes, in other words, less than $150 \times 10^{9} / \mu$ l.The normal number of platelets per microliter of blood in adults is between the ranges of 150,000 to 450,000 platelets/ $\mu$ l. TCP explicitly rises for different reasons. These include types of cancers, hazardous chemicals and combinations of different regimens of drugs like chemotherapies, non-steroidal anti-inflammatory drugs, involvement of genetic inheritance and viral infections (Izak \& Bussel, 2014; $\mathrm{NHLBI}, 2020)$. Specifically in dengue infected patients, momentary as well as transient disorder occurs during DF, which is likely to be caused by the consistently high viral load and contributes to malfunction of the endothelial vascular system. Disruption of the coagulation mechanism may lead to plasma discharge, shock and haemorrhages (WHO, 2009). Reduction in platelet production and subsequent clearance of platelets from peripheral blood in DV infection is a major contributing factor of thrombocytopenia, but platelet destruction is more prominent in the case of DV infection. The exact mechanism of platelet destruction is unknown, however the binding of antibody-opsonized DV with CD32 (FcyRII) on the thrombocytes marks the thrombocyte for destruction by phagocytosis from macrophages (Pesaro, D'Amico, \& Aranha, 2007; Sridharan et al., 2013). TCP and haemorrhages are common faces of DF and DHF because TCP mostly disappears by itself on the $10^{\text {th }}$ day of the onset of the dengue infection; very rare cases have been confronted to have a delayed TCP after the $10^{\text {th }}$ day. However, all these delayed cases of TCP behave exactly like Immune TCP Purpura (ITP) (Verma, Hamide, Wadhwa, \& Sivamani, 2013). ITP is a common blood disorder, which is denoted by muco cutaneous haemorrhage and decreased thrombocytes. This is an auto-immune disorder in which pathogenic immunoglobulin has an affinity to bind to the host thrombocytes or DV attaches itself to platelets, causing their rapid destruction. ITP is further categorized into two etiological dependent categories which are primary and secondary or timely based; it depends on duration after diagnosis, such as acute or chronic (Leong \& Srinivas, 1993; Recht, 2009).

\section{METHODS}

This theoretical narrative review is merely grounded on hypotheses and research papers showing the positive or negative results with corticosteroids, TPO-R agonist platelet trans- fusion and IVIG transfusion in patients affected by DF, DHF and DSS after going through a web-based search on different search engines. The electronic databases PubMed, Cochrane Library, Google Scholar and Science Direct were searched for articles published from January 1990 to June 2020. A total of 55 published articles, including clinical trials, cross-sectional studies, case reports and meta-analysis reviews, were retrieved and reviewed regarding the treatment approaches in Dengueassociated TCP, including simple dengue fever, dengue haemorrhagic fever and dengue shock syndrome or expanded dengue syndrome. Out of 55 published research studies, 26 studies were reviewed according to the type of treatment to extrude outcomes that favour the reversal of TCP or platelets increase favours the treatment or not.

\section{Approaches to treat thrombocytopenia}

Prevention of TCP according to the World Health Organization

According to the $\mathrm{WHO}$, treatment and management protocols of dengue patients are based on "Group A, B \& C". In category A, dengue patients are mostly reported to have a high grade fever and are given only Paracetamol every six hours in 24 hours (along with oral rehydration salts) to reduce fever. This is indicated and other antipyretic drugs are avoided because they are suspected to induce more TCP. Group B consists of patients who reach the critical phase and are hospitalized followed by IV solutions (normal saline, ringer lactate) to avoid plasma loss. Group C patients are often serious, mostly suffering from dengue shock and other dengue haemorrhagic complications, which lead to plasma leakage, respiratory distress, severe haemorrhages and other organs' impairment. However, these patients are treated with isotonic crystalloid solution, blood transfusion (in case of severe bleeding) and platelet transfusion (for severe TCP) including other important steps detailed in Table 1. (WHO et al., 2009)

\section{Use of Thrombopoietin Receptor Agonist (TPO-R) in pre- vention of TCP \\ i. Use of Recombinant Human Interleukin 11 (rhIL-11; Oprelvekin) in TCP}

Recombinant Human Interleukin 11(rhlL-11), also known as Oprelvekin and authorized by the US FDA in 1997, was indicated for severe TCP. The rhIL-11 is a cytokine that acts together with different hematopoietic and non-hematopoietic cells. It is developed in E-coli by Recombinant DNA technology and this varies by the absence of the "amino-terminal praline residue" from endogenous interleukin 11 (Dorner, Goldman, \& Keith, 1997; Health, 2017). RhIL-11 is a thrombopoietic growth factor; it promotes the proliferation of megakaryocyte progenitor cells and increases the production of thrombocytes (Medscape, 2020). Evaluation of rhIL-11 from two clinical trials conducted in Pakistan found over 40 patients with less than $30 \mathrm{~K} / \mu \mathrm{L}$ platelets. RhIL-11 was found to have improved platelet count at convalescence. Furthermore, platelet counts increased by $20 \mathrm{~K} / \mu \mathrm{L}$ over baseline at 48 hours, without any bleeding complications among the placebo group (Nisar, Shaban, \& Shah, 2018; Suliman, Qayum, \& Saeed, 2014). Rodriguez et al, reported a dengue patient followed by anaemia, leukopenia, TCP. According to his studies, treatment started with steroidal interventions of 
Table 1. World Health Organization-approved therapeutic approaches (Organization et al., 2009).

\begin{tabular}{|c|c|c|c|c|c|}
\hline Category & Description & Treatment & Dosing & Purpose & Caution \\
\hline \multirow[t]{2}{*}{$\begin{array}{l}\text { Group } \\
\text { (A) }\end{array}$} & \multirow[t]{2}{*}{$\begin{array}{l}\text { Developing } \\
\text { warning signs }\end{array}$} & $\begin{array}{l}\text { Oral rehydration } \\
\text { salt (ORS) }\end{array}$ & $\begin{array}{l}\text { Adequate fluid } \\
\text { intake }\end{array}$ & $\begin{array}{l}\text { Substitute } \\
\text { for fever and } \\
\text { vomiting losses }\end{array}$ & $\begin{array}{l}\text { Sugar-glucose fluids can } \\
\text { exacerbate the effect of } \\
\text { hyperglycaemia. }\end{array}$ \\
\hline & & Paracetamol & - & $\begin{array}{l}\text { To relieve high } \\
\text { fever }\end{array}$ & Avoid other NSAIDs. \\
\hline $\begin{array}{l}\text { Group } \\
\text { (B) }\end{array}$ & $\begin{array}{l}\text { A patient who } \\
\text { developed } \\
\text { warning signs }\end{array}$ & $\begin{array}{l}0.9 \% \text { Normal } \\
\text { saline, Ringer's } \\
\text { lactate, or } \\
\text { Hartmann's } \\
\text { solution }\end{array}$ & $\begin{array}{l}\text { Start with } \\
5-7 \mathrm{ml} / \mathrm{kg} / \mathrm{hour} \text { for } \\
1-2 \text { hours; } \\
\text { reduce according to } \\
\text { clinical response }\end{array}$ & $\begin{array}{l}\text { To replace } \\
\text { losses from } \\
\text { plasma leakage }\end{array}$ & $\begin{array}{l}\text { Monitor warning signs such } \\
\text { as haematocrit, } \\
\text { white blood cell count, } \\
\text { platelet counts. }\end{array}$ \\
\hline \multirow[t]{4}{*}{$\begin{array}{l}\text { Group } \\
\text { (C) }\end{array}$} & $\begin{array}{l}\text { 1-severe } \\
\text { plasma leakage } \\
\text { leading to DS } \\
\text { 2-fluid } \\
\text { retention and } \\
\text { respiratory } \\
\text { distress } \\
\text { 3-severe } \\
\text { bleeding } \\
\text { 4- severe organ } \\
\text { impairment }\end{array}$ & $\begin{array}{l}\text { 1-Isotonic } \\
\text { crystalloid } \\
\text { solution } \\
\text { 2-Blood } \\
\text { Transfusion } \\
\text { (for severe } \\
\text { bleeding) }\end{array}$ & - & $\begin{array}{l}\text { Plasma loss } \\
\text { replacement }\end{array}$ & $\begin{array}{l}\text { For obese patients, } \\
\text { IBM should be used for } \\
\text { calculating fluid infusion } \\
\text { rates. }\end{array}$ \\
\hline & $\begin{array}{l}\text { Treatment of } \\
\text { shock }\end{array}$ & $\begin{array}{l}\text { Crystalloid } \\
\text { solutions }\end{array}$ & $\begin{array}{l}\text { 5- } 10 \mathrm{~mL} / \mathrm{kg} / \mathrm{hr} \text { over } \\
\text { one hour }\end{array}$ & $\begin{array}{l}\text { Plasma loss } \\
\text { replacement }\end{array}$ & $\begin{array}{l}\text { Followed by reassessing the } \\
\text { patient's vital signs }\end{array}$ \\
\hline & \multirow{2}{*}{$\begin{array}{l}\text { Treatment of } \\
\text { haemorrhagic } \\
\text { complications }\end{array}$} & $\begin{array}{l}\text { 1-Platelet } \\
\text { transfusions }\end{array}$ & - & for severe TCP & \\
\hline & & $\begin{array}{l}\text { 2-Blood } \\
\text { transfusion }\end{array}$ & $\begin{array}{l}5-10 \mathrm{ml} / \mathrm{kg} \text { fresh- } \\
\text { packed red cells or } \\
10-20 \mathrm{~mL} / \mathrm{kg}\end{array}$ & Severe bleeding & $\begin{array}{l}\text { 1-Blood transfusion must be } \\
\text { given with care because of } \\
\text { the risk of fluid overload } \\
2-\text { Consider repeating the } \\
\text { blood transfusion if there is } \\
\text { further blood loss }\end{array}$ \\
\hline
\end{tabular}

IV hydrocortisone along with subcutaneous filgrastim 300mcg. Neutropenia was resolved after the 4th day of onset but TCP rose transiently and dropped unexpectedly even with daily transfusions of rh-IL-11 (Rodriguez-Mejorada, Rosel-Gomez, Rosado-Castro, \& Ruiz-Argüelles, 2010) see Table 2.

\section{ii. Use of Eltrombopag in prevention TCP}

Eltrombopag olamine is a small molecule thrombopoietin receptor agonist (TPO-R) for oral administration. It interacts with the transmembrane domain of the TPO receptor (also known as CMpl), thus it increases thrombocyte production by signal-

Table 2. Recombinant Human Interleukin 11 (rhIL-11) in DF.

\begin{tabular}{|c|c|c|c|c|c|c|c|}
\hline Sn & Study & Study Type & $\begin{array}{l}\text { Age } \\
\text { group }\end{array}$ & Disease & Dose & $\begin{array}{l}\text { Platelet } \\
\text { increase } \\
\text { favours the } \\
\text { rhlL-11 }\end{array}$ & Outcome measures \\
\hline 01 & $\begin{array}{l}\text { Muhammad } \\
\text { et al } \\
2011\end{array}$ & $\begin{array}{l}\text { Randomized } \\
\text { double-blind } \\
\text { placebo control }\end{array}$ & $\begin{array}{l}<50 Y \\
\mathrm{~N}=20 \\
\text { Control } \\
\text { group }\end{array}$ & $\begin{array}{l}\text { Dengue } \\
\text { Fever }\end{array}$ & $1.5 \mathrm{mg} / \mathrm{SC}$ & Yes & $\begin{array}{l}\text { Significant Rise in } \\
\text { Platelets }\end{array}$ \\
\hline 02 & $\begin{array}{l}\text { Jazirah } \\
\text { Rehman } \\
2011\end{array}$ & $\begin{array}{l}\text { Randomized } \\
\text { double-blind } \\
\text { placebo control }\end{array}$ & $\begin{array}{l}<50 Y \\
40\end{array}$ & $\begin{array}{l}\text { Dengue } \\
\text { Fever }\end{array}$ & $1.5 \mathrm{mg} / \mathrm{SC}$ & Yes & $\begin{array}{l}\text { Significant Rise in } \\
\text { Platelets } \\
\text { (Nisar et al., 2018; } \\
\text { Suliman et al., } \\
\text { 2014) }\end{array}$ \\
\hline
\end{tabular}


ling cascades that induce proliferation and differentiation from bone marrow progenitor cells. However, it is being considered as a second treatment option in ITP patients (FDA, Aug 26, 2014; Vishnu \& Aboulafia, 2016). Literature review from the last decade does not show much valuable data that supports the treatment of TCP in dengue patients with eltrombopag. Somehow, an ongoing phase II clinical trial of 100 dengue patients followed by DF, DHF and DSS in Dhaka India is pipelined to "evaluate the safety efficacy of eltrombopag in TCP" sponsored by (Incepta Pharmaceuticals Ltd) (Sajib Chakraborty, 2020)

\section{iii. Use of Romiplostim in prevention of TCP}

Romiplostim also belongs to the TPO- R agonist class of drugs. Its subcutaneous administration binds the romiplostim to TPO-R, which turns to receptor activation and results in increasing platelet production. Due to the absence of peptide sequence of endogenous TPO, cross-reactive antibodies were never reported. It is being broadly used to treat immune TCP as compared to other oral forms (Soff et al., 2019). The US FDA has approved its indication for adult patients and children above one year with ITP who suffered with an insufficient response to corticosteroids, immunoglobulins, or splenectomy (US. FDA, 2008). In vitro, it binds to c-Mpl receptors and Mpl-transfected cells (BaF3-Mpl cells). Like other TPO-R agonists, it is presumably internalized upon binding to the c-Mpl receptor, triggering activation of JAK-STAT and related pathways. When co-cultured with murine bone marrow cells, it shows the growth of colony forming unit (CFU) megakaryocytes and promotes the proliferation and maturation of megakaryocytes. Furthermore, it exhibited reflective platelet production in rats, mice and primates (Perez-Ruixo, Green, Doshi, Wang, \& Mould, 2012). Rodriguez-Mejorada et al, reported a case series of a 56-yearold female dengue-positive patient followed by anaemia, leukopenia, TCP. Prior intention of filgrastim (300 mcg/day) and hydrocortisone (300 mg/day) received good results with sudden dropdown of platelets. However, secondary intention with romiplostim ( $4 \mathrm{mcg} / \mathrm{kg} / \mathrm{wk}$.) reduced TCP in the next 48 hours with continuous elevation without any side effects (RodriguezMejorada et al., 2010).

\section{IMMUNOLOGICAL APPROACHES IN PREVENTION OF TCP}

\section{i. Intravenous Immunoglobulin (IVIG)}

Intravenous Immunoglobulin (IVIG) is the blood product of about 1500 blood donors per batch made from the serum. It is the choice of treatment for antibody-deficient patients. IVIG is usually given thrice weekly ( $200 \mathrm{mg} / \mathrm{kg}$ to $400 \mathrm{mg} / \mathrm{kg}$ ) to patients. A high dose of IVIG (hdIVIG) is frequently prescribed at $2 \mathrm{~g} / \mathrm{kg} / \mathrm{month}$, which is indicated as an immunomodulatory mediator in the context of immune and inflammatory conditions. Initially, hdIVIG was prescribed only in children for immune thrombocytopenic purpura (ITP). It was first established as an immunomodulatory mediator to manage ITP in adults as well (Jolles, Sewell, Misbah, \& immunology, 2005). Kumar et al, reported a case of 30-year-old woman with ITP followed by a dengue-positive report. Treatment of IV platelets infusion could not indicate much of a desired outcome. Respectively, multiple transfusions of platelet units from single and multiple donors were provided, with no significant result. But, transfusion of IVIG (2 g/ $\mathrm{kg})$ over two days resulted an immediate rise in the platelet count, up to $35 \times 10^{9} / \mathrm{L}, 78 \times 10^{9} / \mathrm{L}$ and $130 \times 10^{9} / \mathrm{L}$ 35 with IVIG at $12 \mathrm{hrs}$, 36hrs and $72 \mathrm{hrs}$ (Kumar, Gupta, Soneja, \& Biswas, 2018). Subbiah et al, also reported a dengue patient case, mentioned as (14×109/L) platelets. Five continuous days of IVIG infusion by $0.5 \mathrm{~g} / \mathrm{kg}$ administration significantly helped the patient recover from dengue capillary leak syndrome (Subbiah, Mahajan, Yadav, \& Agarwal, 2018). Respectively, Kumar et al, stated in a case report of a patient with a persistent decrease of platelets from $15 \times 109 / \mathrm{L}$ to further low levels. Platelet transfusion and high doses of steroids were not successful. However, a transfusion of IVIG on day 9 followed by $1 \mathrm{~g} / \mathrm{kg}$ showed a profound response: day 10 - 40,000, day 11 - 90,000 and

Table 3. Use of IVIG in Dengue Fever-induced TCP.

\begin{tabular}{|c|c|c|c|c|c|c|c|}
\hline Sn/Ref & $\begin{array}{l}\text { Study } \\
\text { Type }\end{array}$ & Country & $\begin{array}{l}\text { Age/ } \\
\text { Gender }\end{array}$ & $\begin{array}{l}\text { Medical } \\
\text { Condition }\end{array}$ & Dose & $\begin{array}{l}\text { Platelet } \\
\text { increase favours } \\
\text { the rhIL-11 }\end{array}$ & $\begin{array}{l}\text { Outcome } \\
\text { measures }\end{array}$ \\
\hline $\begin{array}{l}\text { (Kumar et al., } \\
\text { 2018) }\end{array}$ & $\begin{array}{l}\text { Case } \\
\text { report }\end{array}$ & India & $30 \mathrm{~F}$ & $\begin{array}{l}\text { Dengue Fever } \\
\text { ITP }\end{array}$ & $\begin{array}{l}\text { IVIG at a } \\
\text { dose of } 2 \mathrm{~g} / \\
\text { kg body } \\
\text { weight over } 2 \\
\text { days. }\end{array}$ & Yes & $\begin{array}{l}\text { No significant } \\
\text { difference in the } \\
\text { platelet counts } \\
\text { at the time of } \\
\text { discharge. Similar } \\
\text { early increase in } \\
\text { platelet count with } \\
\text { the use of anti-D. }\end{array}$ \\
\hline $\begin{array}{l}\text { (Subbiah et } \\
\text { al., 2018) }\end{array}$ & $\begin{array}{l}\text { Case } \\
\text { report }\end{array}$ & India & $45 \mathrm{M}$ & $\begin{array}{l}\text { stable graft } \\
\text { function } \\
\text { Dengue } \\
\text { Positive } \\
\text { TCP }\end{array}$ & $\begin{array}{l}0.5 \mathrm{~g} / \mathrm{kg} \text { of } \\
\text { IVIG was } \\
\text { administered } \\
\text { daily for } \\
5 \text { days }\end{array}$ & Yes & $\begin{array}{l}\text { The patient } \\
\text { improved } \\
\text { significantly } \\
\text { with IVIG } \\
\text { administration. }\end{array}$ \\
\hline $\begin{array}{l}\text { (Kumar et al., } \\
\text { 2016) }\end{array}$ & $\begin{array}{l}\text { Case } \\
\text { report }\end{array}$ & India & $21 \mathrm{~F}$ & DHF & $1 \mathrm{~g} / \mathrm{kg}$ & Yes & $\begin{array}{l}\text { Better response to } \\
\text { IVIG and failure to } \\
\text { respond to steroid } \\
\text { and IV platelet } \\
\text { infusion. }\end{array}$ \\
\hline
\end{tabular}


on day 12 - 125,000 per cu mm (Kumar, Prabhat, et al, 2016). Moreover, only one RCT in a 2007 study of 31 dengue patients by Dimaano et al reported that IV-IG was found to show better outcomes in correcting TCP in dengue patients as compared to the placebo group (Dimaano et al., 2007) (Table 3).

\section{ii. Anti-D Immune Globulin}

Anti-D immune globulin is an IgG fraction of plasma prepared from "D-Positive Red Cell Immunized" individuals and likely rich in polyclonal Anti-D specificities. This is used to avoid alloimmunization in $\mathrm{Rh}^{-i v e}$ mothers giving birth to $\mathrm{Rh}^{+i v e}$ infants. AntiD immune globulin blocks Fcy receptors and reduces immune destruction in patients followed by ITP. Hence, it recovers TCP in dengue patients (Brinc \& Lazarus, 2009; Lazarus, Freedman, \& Semple, 1998). Pannu et al reported in an open-label, randomized interventional study in 2007 on over 30 Rh+ive patients with serology-proven dengue positivity with severe TCP (platelet count $\left.\leq 20,000 / \mathrm{mm}^{3}\right)$. The two groups were compared concerning their response in the form of a rise in platelet count. The primary outcome was a rise in platelet count $\geq 50,000$ / $\mathrm{mm} 3$ above the baseline after a period of 48 hours of administering an anti-D injection in the intervention group. The rise in platelets was more rapid in the intervention group and was significant at 24hrs, 36hrs, and 48hrs ( $p=0.0001,<0.0001$, and $<0.0001$, respectively (Pannu et al., 2017). Kharya et al reported a 16-year-old patient with DHF and serious refractive TCP undergoing $6800 / \mathrm{mm}^{3}$ of platelets value. It is observed that the average count of platelets after 48hrs followed by administration of IG Anti-D in patients showed a positive response by $37,800 / \mathrm{mm}^{3}$ platelets (Kharya, Yadav, Katewa, Sachdeva, \& Oncology, 2011). Anti-D immune globulin confirmed in RCT reported by Rajapakse et al, stated that dengue patients suc- cessfully recovered with anti-D immune globulin (Rajapakse, de Silva, Weeratunga, Rodrigo, \& Fernando, 2017).

\section{OTHER APPROACHES IN PREVENTION OF TCP}

\section{i. Use of Corticosteroids in prevention TCP}

According to this review, inadequate evidence supported the effectiveness of corticosteroids (CS) in deranged immune systems due to dengue. Besides, use of CS is not specified in WHO guidelines for dengue management and treatment protocols. However, physicians objectively use corticosteroids to explain their use in an immunological context (Kularatne, 2005; Medin \& Rothman, 2006). Clinical studies have shown conflicting outcomes and unconvincing results with corticosteroids treatments. Only a few positive responses came out by min et al, in a clinical trial in which children were treated with hydrocortisone hemi succinate followed by dose tapering for three days, but results seem to be significant in the children solely greater than eight years of age (Min, Aye, Shwe, \& Swe, 1975). Verma et al reported a case of a 65 years old patient who was diagnosed with dengue and immune-mediated TCP. The patient was started with oral prednisolone $1 \mathrm{mg} / \mathrm{kg}$ after the trial of four units of platelet transfusion, hence, CS responded to achieve the desired effects (Verma et al., 2013). Other RCTs and case reports mentioned in (Table 4) did not show an efficient haemodynamic improvement in favour of corticosteroids (hydrocortisone hemisuccinate, methyl prednisolone, prednisolone and dexamethasone) in DS and DHF (Boo, Lim, P'ng, Liam, \& Huan, 2019; Kohli, Saharan, Lodha, \& Kabra, 2008; Kularatne et al., 2009; Pongpanich, Bhanchet, Phanichyakarn, \& Valyasevi, 1973; Sumarmo, Talogo, Asrin, Isnuhandojo, \& Sahudi, 1982; Tassniyom, Vasanawathana, Chirawatkul, \& Rojanasuphot, 1993; Widya \& Martoatmodjo, 1975).

Table 4. Corticosteroid outcomes In Dengue associated TCP.

\begin{tabular}{|c|c|c|c|c|c|c|c|c|c|}
\hline SN & Study & Study Type & Year & Drug & Dose & $\begin{array}{l}\text { Age } \\
\text { Group } \\
\text { No of } \\
\text { Patients }\end{array}$ & disease & $\begin{array}{l}\text { Favours } \\
\text { Steroid }\end{array}$ & $\begin{array}{l}\text { Outcome } \\
\text { measures }\end{array}$ \\
\hline 1 & $\begin{array}{l}\text { (Kohli et al., } \\
\text { 2008) }\end{array}$ & Case Report & 2008 & N/A & $\begin{array}{l}\text { N/A } \\
\text { IV }\end{array}$ & 11 Yrs 01 & $\begin{array}{l}\text { DSS, } \\
\text { DHF }\end{array}$ & No & Patient died \\
\hline 2 & $\begin{array}{l}\text { (Kularatne } \\
\text { et al., 2009) }\end{array}$ & $\begin{array}{l}\text { Placebo } \\
\text { controlled } \\
\text { study }\end{array}$ & 2009 & $\begin{array}{l}\text { Dexametha- } \\
\text { sone }\end{array}$ & $\begin{array}{l}2 \mathrm{mg} / \mathrm{IV} 8 \mathrm{~h} \\
\text { for } 24 \mathrm{~h}\end{array}$ & $\begin{array}{l}>12 \text { Yrs } \\
100\end{array}$ & Acute DF & No & $\begin{array}{l}\text { No significant } \\
\text { response }\end{array}$ \\
\hline 3 & $\begin{array}{l}\text { (Tam et al., } \\
\text { 2012) }\end{array}$ & $\begin{array}{l}\text { Random- } \\
\text { ized } \\
\text { placebo } \\
\text { control }\end{array}$ & 2012 & Prednisolone & $\begin{array}{l}\text { Lower dose } \\
0.5 \mathrm{mg} / \mathrm{kg} \\
\text { Higher dose } \\
2 \mathrm{mg} / \mathrm{kg}\end{array}$ & $\begin{array}{l}05-20 \\
\text { Yrs }\end{array}$ & $\begin{array}{l}\text { Dengue } \\
\text { with } \\
\text { hypo- } \\
\text { volemic } \\
\text { shock }\end{array}$ & No & $\begin{array}{l}\text { No reduction } \\
\text { represented } \\
\text { to counter the } \\
\text { Dengue shock }\end{array}$ \\
\hline 4 & $\begin{array}{l}\text { Shailendra } \\
\text { et al,2012) } \\
\text { (Verma et } \\
\text { al., 2013) }\end{array}$ & Case Report & 2013 & Prednisolone & $1 \mathrm{mg} / \mathrm{kg} / \mathrm{PO}$ & 65 Yrs 01 & DF & Yes & $\begin{array}{l}\text { Promptly } \\
\text { responded to } \\
\text { Prednisolone }\end{array}$ \\
\hline 5 & $\begin{array}{l}\text { (Boo et al., } \\
\text { 2019) }\end{array}$ & Case Report & 2019 & $\begin{array}{l}\text { Methyl } \\
\text { prednisolone }\end{array}$ & $1 \mathrm{mg} / \mathrm{kg} / \mathrm{PO}$ & $\begin{array}{l}13 \mathrm{Yrs} \\
01\end{array}$ & $\begin{array}{l}\text { ITP post } \\
\text { Dengue } \\
\text { infection }\end{array}$ & NO & $\begin{array}{l}\text { Patient died } \\
\text { after three } \\
\text { months }\end{array}$ \\
\hline
\end{tabular}




\section{ii. Platelet transfusion}

Platelet Transfusion (PT) is commonly used during or after the use of chemotherapy, for wounded/injured patients and for those who are undergoing surgery or an invasive investigation. Hypo-proliferative TCP requires PT; it is acquired in prophylactic strategies such as acute leukaemia, stem cell therapies and aplasias following intensive myeloid-suppressive antineoplastic therapies and dengue associated acute TCP (Humbrecht, Kientz, \& Gachet, 2018; Roy, 2019). Lye et al reported that in 2009 at Tan Tock Seng Hospital Singapore, 256 dengue-infected patients had TCP followed by average $20,000 / \mathrm{mm} 3$ platelets. Without prior bleeding, of the 188 patients who were transfused with platelets. Although subsequent bleeding, platelet increment, and recovery were almost found similar between two groups of patients, those who received the transfusion compared to those who did not, had similar outcomes. Prophylactic PT was ineffectual in stopping bleeding in the patients (Lye, Lee, Sun, \& Leo, 2009). In a study reported by Pothapregada et al, in 2012, involving children aged 0 - 12 years old, confirmed with DF. Out of a total of 17 children 17 were transfused with platelets units. Among the children, 12 had an average PC of over $20,000 / \mathrm{mm}^{3}$, while the other children ranged between $20000 / \mathrm{mm}^{3}$ and $50000 / \mathrm{mm}^{3}$. Children who received platelet transfusions recovered completely (Pothapregada, Kamalakannan, \& Thulasingam, 2015). Respectively, previous study reported prophylactic platelet transfusion leads to no significant difference between two groups (Archuleta et al., 2019; Assir \& Ahmad, 2017; Lee et al., 2016). According to Soumya et al, there is a large lack of evidence-based platelet transfusion guidelines when patients develop bleeding symptoms in dengue infection. Inappropriate usage of platelets for stable patients with low platelet count causes decreased availability of platelets. There is a need for decreasing unwanted transfusions, which can be achieved by strict adherence to the British Committee for Standardization in Hematology (BCSH) Guidelines (Soumya, Das, \& Kalyani, 2019) (Table 5).

\section{FUTURE DIRECTION}

Scientists should be focused on elaborating the role of all the approaches and treatment options in dengue associated with TCP for improving the production and maintenance of platelets to reduce morbidity and mortality. TPO-R agonists and growth factors such as RhIL-11 (oprelvekin) are the easiest approaches if these options are appropriately evaluated for their safety and effectiveness via RCTs in a large group of the population along with long-term exposure studies. The safety and efficacy profile of TPO-R agonist and RhIL-11 in dengue patients should be determined in order to choose the best dosage schedule in consideration of the potential side effects and adverse effects and other toxicities like mutagenicity, carcinogenicity, tumorigenicity and withdrawal effects on TCP.

\section{CONCLUSION}

Dengue is an insect-borne viral disease that requires medical attention because it may lead to TCP and life-threatening conditions. CS is the most common choice of drugs used to treat TCP, however, the WHO has not recommended it in its guidelines. CS is well known to have an immunosuppressant behavioural response in patients, especially in the case of DV. The antibody-virus complex is more prone to target the cell and leads to more destruction of thrombocytes. For future outcomes, researchers should thoroughly assess the use of CS in a randomised controlled trial. Although RhIL-11 is useful for treating chemotherapy-induced TCP, Rh IL-11 (Oprelvekin) is excessively used along with chemotherapy in major hospitals in Pakistan and other developed countries to counter chemotherapeutic-induced TCP. However, only two small studies reported in Pakistan support the use of RhIL-11 in the treatment of TCP due to dengue infection. Further, detail in this context requires proper assessment for safety, efficacy and risk factors. Similarly, very limited data is available about Romiplostim and eltrombopag for the reversal of TCP. This limited finding indicates the imperative consideration to choose these treatment modalities for improvement of deadly TCP in dengue. However, unbiased double-blind randomized clinical trials must be carried out to assess the efficacy, safety, side effects and costeffectiveness.

In addition to TPO-R agonists, Anti-D immune globulin, Intravenous Immunoglobulin G (iv-ig) and platelet transfusion can

Table 5. Use of prophylactic transfusion of Platelets to cover TCP.

\begin{tabular}{|c|c|c|c|c|c|c|c|c|}
\hline $\begin{array}{l}\text { Sn / } \\
\text { Ref }\end{array}$ & Year & Study Type & Country & $\begin{array}{l}\text { Age / } \\
\text { Nos }\end{array}$ & $\begin{array}{l}\text { Medical Condi- } \\
\text { tion }\end{array}$ & $\begin{array}{l}\text { Mean } \\
\text { PT Units }\end{array}$ & $\begin{array}{l}\text { Favours } \\
\text { PT }\end{array}$ & $\begin{array}{l}\text { Outcome } \\
\text { measures }\end{array}$ \\
\hline $\begin{array}{l}\text { (Lye et al., } \\
\text { 2009) }\end{array}$ & 2009 & $\begin{array}{l}\text { Retrospective } \\
\text { cohort }\end{array}$ & Singapore & $\begin{array}{l}(34) \\
256\end{array}$ & $\begin{array}{l}\text { Dengue infection } \\
\text { TCP }\end{array}$ & 4 Units & No & $\begin{array}{l}\text { Not recovered } \\
\text { with PT }\end{array}$ \\
\hline $\begin{array}{l}\text { (Pothapre- } \\
\text { gada et al., } \\
2015 \text { ) }\end{array}$ & 2015 & $\begin{array}{l}\text { Observational } \\
\text { Study }\end{array}$ & India & $\begin{array}{l}(0-12) \\
261\end{array}$ & $\begin{array}{l}\text { Dengue infection } \\
\text { DSS }\end{array}$ & $\mathrm{N} / \mathrm{A}$ & Yes & $\begin{array}{l}\text { Recovered } \\
\text { completely } \\
\text { with PT }\end{array}$ \\
\hline $\begin{array}{l}\text { (Lee et al., } \\
\text { 2016) }\end{array}$ & 2016 & $\begin{array}{l}\text { Non-Ran- } \\
\text { domized } \\
\text { observational } \\
\text { study }\end{array}$ & Singapore & $\begin{array}{l}22-65 \\
788\end{array}$ & $\begin{array}{l}\text { Dengue infection } \\
\text { Bleeding }\end{array}$ & $\mathrm{N} / \mathrm{A}$ & No & $\begin{array}{l}\text { Not recovered } \\
\text { with PT }\end{array}$ \\
\hline $\begin{array}{l}\text { (Assir \& } \\
\text { Ahmad, } \\
2017 \text { ) }\end{array}$ & 2017 & $\begin{array}{l}\text { Open-Label } \\
\text { Randomized } \\
\text { Clinical Trial }\end{array}$ & Pakistan & $\begin{array}{l}N / A \\
372\end{array}$ & $\begin{array}{l}\text { Dengue infection } \\
\text { without bleeding }\end{array}$ & 4 Units & No & $\begin{array}{l}\text { Recovered } \\
\text { completely } \\
\text { with PT }\end{array}$ \\
\hline
\end{tabular}


be considered to reduce TCP. However, these choices were found to have very limited literature support in case of dengue. Besides, IVIG is supported by few case reports that are conducted and reported in India only, while many studies suggest platelet transfusion favours the reversal of TCP but carries many other complications because PTs are obtained from multiple donors and are more prone to immunological responses in patients. A detailed insight into their role in the treatment of DHF TCP patients is urgently required. Keeping in view these complications with PT, IVIG and Anti-D immune globuline transfusion and others, TPO-R like eltrombopag and romiplostim and growth factor like Rh IL-11 (oprelvekin) are good and easy approaches which should be tried in the management of TCP in dengue patients.

Peer-review: Externally peer-reviewed.

Conflict of Interest: The authors have no conflict of interest to declare.

Financial Disclosure: Authors declared no financial support.

\section{REFERENCES}

- $\quad$ Archuleta, S., Chia, P. Y., Wei, Y., Syed-Omar, S. F., Low, J. G., Oh, H. M., ... Kamarulzaman, A. (2019). Predictors and Clinical Outcomes of Poor Platelet Recovery in Adult Dengue With Thrombocytopenia: A Multicenter, Prospective Study. Clinical Infectious Diseases, 71(2), 383-389.

- Assir, M. Z. K., \& Ahmad, F. (2017). Prophylactic platelet transfusion does not reduce risk of clinical bleeding in adults with dengue and thrombocytopaenia. BMJ Evidence-Based Medicine, 22(6), 225.

- Boo, Y., Lim, S., P'ng, H., Liam, C., \& Huan, N. (2019). Persistent thrombocytopenia following dengue fever: What should we do? Malaysian Family Physician: the Official Journal of the Academy of Family Physicians of Malaysia, 14(3), 71-73.

- $\quad$ Brinc, D., \& Lazarus, A. H. (2009). Mechanisms of anti-D action in the prevention of hemolytic disease of the fetus and newborn. ASH Education Program Book, 2009(1), 185-191.

- Dimaano, E. M., Saito, M., Honda, S., Miranda, E. A., Alonzo, M. T., Valerio, M. D., ... Oishi, K. (2007). Lack of efficacy of high-dose intravenous immunoglobulin treatment of severe thrombocytopenia in patients with secondary dengue virus infection. American Journal of Tropical Medicine and Hygiene, 77(6), 1135-1138.

- Dorner, A. J., Goldman, S. J., \& Keith, J. C. (1997). Interleukin-11. BioDrugs, 8(6), 418-429.

- FDA (Aug 26, 2014). PROMACTA* (eltrombopag). Retrieved from https://www.accessdata.fda.gov/drugsatfda_docs/ label/2017/207027s003lbl.pdf

- US. FDA (2008). Highlight of prescribing information. Retrieved from https://www.accessdata.fda.gov/drugsatfda_docs/ label/2008/125268lbl.pdf

- National Institutes of Health. (2017). LiverTox: clinical and research information on drug-induced liver injury. Nih. gov https:// livertox. nih. gov

- Hosangadi, D. (2019). The global rise of dengue infections. Retrieved from https://www.outbreakobservatory.org/outbreakthursday-1/3/21/2019/the-global-rise-of-dengueinfections?rq=dengue

- Humbrecht, C., Kientz, D., \& Gachet, C. (2018). Platelet transfusion: Current challenges. Transfusion Clinique et Biologique, 25(3), 151164. doi:10.1016/j.tracli.2018.06.004

- $\quad$ Izak, M., \& Bussel, J. B. (2014). Management of thrombocytopenia. F1000 Prime Reports, 6, 45
Jolles, S., Sewell, W., \& Misbah, S.A. (2005). Clinical uses of intravenous immunoglobulin. Clinical and Experimental Immunology, 142(1), 1.

- Kalayanarooj, S. (2011). Clinical manifestations and management of dengue/DHF/DSS. Tropical Medicine and Health, 11120801931112080193.

- Kharya, G., Yadav, S. P., Katewa, S., \& Sachdeva, A. (2011). Management of severe refractory thrombocytopenia in dengue hemorrhagic fever with intravenous anti-D immune globulin. Pediatric Hematology and Oncology, 28(8), 727-732.

- Kohli, U., Saharan, S., Lodha, R., \& Kabra, S. (2008). Persistent thrombocytopenia following dengue shock syndrome. The Indian Journal of Pediatrics, 75(1), 82-83.

Kularatne, S. (2005). Survey on the management of dengue infection in Sri Lanka: opinions of physicians and pediatricians. Southeast Asian Journal of Tropical Medicine and Public Health, 36(5), 1198.

- Kularatne, S., Walathara, C., Mahindawansa, S., Wijesinghe, S., Pathirage, M., Kumarasiri, P., \& Dissanayake, A. (2009). Efficacy of low dose dexamethasone in severe thrombocytopenia caused by dengue fever: a placebo controlled study. Postgraduate Medical Journal, 85(1008), 525-529.

- Kumar, P., Charaniya, R., Ghosh, A., \& Sahoo, R. (2016). Intravenous immunoglobulin responsive persistent thrombocytopenia after dengue Haemorrhagic fever. Journal of Clinical and Diagnostic Research, 10(4), 10.

- $\quad$ Kumar, V., Gupta, K., Soneja, M., \& Biswas, A. (2018). Intravenous immunoglobulin for severe thrombocytopenia in secondary dengue. Case Reports, 2018, bcr-2018.

- $\quad$ Lazarus, A. H., Freedman, J., \& Semple, J. (1998). Intravenous immunoglobulin and anti-D in idiopathic thrombocytopenic purpura (ITP): mechanisms of action. Transfusion Science, 19(3), 289-294.

Lee, T. H., Wong, J. G., Leo, Y. S., Thein, T. L. (2016). Potential harm of prophylactic platelet transfusion in adult dengue patients. Plos Neglected Tropical Diseases, 10(3), 4576.

- Leong, K., \& Srinivas, P. (1993). Corticosteroid-responsive prolonged thrombocytopenia following dengue haemorrhagic fever. Medical Journal of Malaysia, 48, 369-369.

Lye, D. C., Lee, V. J., Sun, Y., \& Leo, Y. S. (2009). Lack of efficacy of prophylactic platelet transfusion for severe thrombocytopenia in adults with acute uncomplicated dengue infection. Clinical Infectious Diseases, 48(9), 1262-1265.

Medin, C. L., \& Rothman, A. L. (2006). Cell type-specific mechanisms of interleukin-8 induction by dengue virus and differential response to drug treatment. The Journal of Infectious Diseases, 193(8), 1070-1077.

Medscape. (2020). oprelvekin (Rx). Retrieved from https://reference.medscape.com/drug/neumega-interleukin-11-oprelvekin-342165\#10

Min, M., Aye, M., Shwe, T., \& Swe, T. (1975). Hydrocortisone in the management of dengue shock syndrome. The Southeast Asian Journal of Tropical Medicine and Public Health, 6(4), 573-579.

Monath, T. P. (2007). Dengue and yellow fever-challenges for the development and use of vaccines. New England Journal of Medicine, 357(22), 2222-2225.

NHLBI. (2020). Thrombocytopenia. Retrieved from https://www. nhlbi.nih.gov/health-topics/thrombocytopenia

Nisar, S., Shaban, M., \& Shah, S. (2018). Role of Recombinant Human Interleukin-11 in Thrombocytopenia Associated with Dengue Fever. International Journal of Advanced Biotechnology and Research, 9(1), 1985-1988.

World Health Organization, Special Programme for Research, Training in Tropical Diseases, World Health Organization. Department of Control of Neglected Tropical Diseases, World Health Organization. Epidemic, \& Pandemic Alert. (2009). Dengue: guidelines for diagnosis, treatment, prevention and control. World Health Organization. 
- Pannu, A. K., Bhalla, A., Singhal, M., Suri, V., Shafiq, N., \& Varma, S. (2017). Safety and efficacy of a single dose of anti-D (WinRho ${ }^{\oplus}$ ) in severe thrombocytopenia secondary to dengue virus infection. Indian Journal of Critical Care Medicine, 21(2), 80.

- $\quad$ Perez Ruixo, J. J., Green, B., Doshi, S., Wang, Y. M., \& Mould, D. R. (2012). Romiplostim dose response in patients with immune thrombocytopenia. The Journal of Clinical Pharmacology, 52(10), 1540-1551.

- Pesaro, A. E., D’Amico, É., \& Aranha, L. F. C. (2007). Dengue: cardiac manifestations and implications in antithrombotic treatment. Scielo Brazil, 89(2), 12-15. https://doi.org/10.1590/S0066$782 \times 2007001400015$

- Pongpanich, B., Bhanchet, P., Phanichyakarn, P., \& Valyasevi, A. (1973). Studies on dengue hemorrhagic fever. Clinical study: an evaluation of steroids as a treatment. Journal of the Medical Association of Thailand, 56(1), 6-14.

- Pothapregada, S., Kamalakannan, B., \& Thulasingam, M. (2015). Role of platelet transfusion in children with bleeding in dengue fever. Journal of Vector Borne Diseases, 52(4), 304-308.

- Rajapakse, S., de Silva, N. L., Weeratunga, P., Rodrigo, C., \& Fernando, S. D. (2017). Prophylactic and therapeutic interventions for bleeding in dengue: a systematic review. Transactions of The Royal Society of Tropical Medicine and Hygiene, 111(10), 433-439. doi:10.1093/trstmh/trx079

- Recht, M. (2009). Thrombocytopenia and anemia in infants and children. Emergency Medicine Clinics of North America, 27(3), 505523.

- Rodriguez-Mejorada, M. S., Rosel-Gomez, G. C., Rosado-Castro, R. A., \& Ruiz-Argüelles, G. J. (2010). Refractory thrombocytopenia associated with dengue hemorrhagic fever responds to romiplostim. Blood, 116 (21), 4668.

- Roy, S. (2019). Thrombopoietin Receptor Agonists: Can These Be the Future Answer to the Deadly Thrombocytopenia in Dengue Fever? Cureus, 11(4).

- $\quad$ Ruberto, I., Marques, E., Burke, D. S., \& Van Panhuis, W. G. (2015). The availability and consistency of dengue surveillance data provided online by the World Health Organization. Plos Neglected Tropical Diseases, 9(4): e0003511. https://doi.org/10.1371/journal. pntd.0003511

- Sajib Chakraborty, A. K. (2019, 15 June 2020). Efficacy and Safety of Eltrombopag to correct thrombocytopenia in moderate to severe dengue patients- a Phase II Randomized Controlled Clinical Trial. Retrieved from https://www.cochranelibrary.com/central/ doi/10.1002/central/CN-02071746/full?highlightAbstract=deng u\%7Celtrombopag\%7Cdengue

- $\quad$ Soff, G. A., Miao, Y., Bendheim, G., Batista, J., Mones, J. V. (2019). Romiplostim treatment of chemotherapy-induced thrombocytopenia. Journal of Clinical Oncology, 37(31), 2892-2898.
Soumya, M. H., Das, S., \& Kalyani, R. (2019). Platelet Transfusion Practice in Dengue Epidemic; Current Trends and Challenges-an Institutional Study. Journal of Blood \& Lymph, 9(4), 255

- Sridharan, A., Chen, Q., Tang, K. F., Ooi, E. E., Hibberd, M. L., \& Chen, J. (2013). Inhibition of megakaryocyte development in the bone marrow underlies dengue virus-induced thrombocytopenia in humanized mice. Journal of Virology, 87(21), 11648-11658.

- $\quad$ Subbiah, A., Mahajan, S., Yadav, R. K., \& Agarwal, S. K. (2018). Intravenous immunoglobulin therapy for dengue capillary leak syndrome in a renal allograft recipient. British Medical Journal. Case Reports, 225225. doi.org/10.1136/bcr-2018-225225

- Suliman, M. I., Qayum, I., \& Saeed, F. (2014). Randomized clinical trial of human interleukin-11 in dengue fever-associated thrombocytopenia. Journal of College of Physicians and Surgeons Pakistan, 24(3), 164-168.

- Sumarmo, D., Talogo, W., Asrin, A., Isnuhandojo, B., \& Sahudi, A. (1982). Failure of hydrocortisone to affect outcome in dengue shock syndrome. Pediatrics, 69(1), 45-49.

- Tam, D. T., Ngoc, T. V., Tien, N. T., Kieu, N. T., Thuy, T. T., Thanh, L. T., ... Wills, B. A. (2012). Effects of short-course oral corticosteroid therapy in early dengue infection in Vietnamese patients: a randomized, placebo-controlled trial. Clinical Infectious Diseases, 55(9), 1216-1224. doi:10.1093/cid/cis655

- Tassniyom, S., Vasanawathana, S., Chirawatkul, A., \& Rojanasuphot, S. (1993). Failure of high-dose methylprednisolone in established dengue shock syndrome: a placebo-controlled, double-blind study. Pediatrics, 92(1), 111-115.

Verma, S. P., Hamide, A., Wadhwa, J., \& Sivamani, K. (2013). Corticosteroid responsive prolonged thrombocytopenia in a case of dengue fever. British Medical Journal. Case Reports, 2013.

- Vishnu, P., \& Aboulafia, D. M. (2016). Long-term safety and efficacy of romiplostim for treatment of immune thrombocytopenia. Journal of Blood Medicine, 7, 99-106. https://doi.org/10.2147/JBM. S80646

WHO. (2019). Outbreak update - Dengue in Pakistan, 1 December 2019. Epidemic and pandemic-prone diseases. Retrieved from http://www.emro.who.int/pandemic-epidemic-diseases/dengue/outbreak-update-dengue-in-pakistan-1-december-2019. html

Widya, M., \& Martoatmodjo, K. (1975). Clinical observations on dengue shock syndrome. An evaluation of steroid treatment. Paediatrica Indonesiana, 15(5/6), 151-160.

- Shailendra, D. T., Ngoc, T. V., Tien, N. T., Kieu, N. T., Thuy, T. T., Thanh, L. T., ... Wills, B. A. (2012). Effects of short-course oral corticosteroid therapy in early dengue infection in Vietnamese patients: a randomized, placebo-controlled trial. Clinical Infectious Diseases, 55(9), 1216-1224. doi:10.1093/cid/cis655 